\title{
PENGARUH MODEL PEMBELAJARAN BERBASIS MASALAH TERHADAP HASIL BELAJAR DAN AKTIVITAS SISWA PADA MATERI POKOK LISTRIK DINAMIS KELAS X SEMESTER II DI SMA MUHAMMADIYAH 8 KISARAN T.A 2014/2015
}

\author{
Sri Rahayu dan Rita Juliani \\ Jurusan Fisika FMIPA Universitas Negeri Medan \\ Jalan Willem Iskandar Pasar V Medan, Sumatera Utara \\ Sri71211@gmail.com
}

\begin{abstract}
ABSTRAK
Pendidikan adalah usaha sadar dan terencana untuk mewujudkan suasana belajar dan proses pembelajaran agar peserta didik secara aktif mengembangkan potensi diri. Penelitian bertujuan untuk mengetahui perbedaan akibat pengaruh dari model pembelajaran berbasis masalah terhadap hasil belajar dan aktivitas siswa. Jenis penelitian adalah quasi experiment dengan desain two group pretest-postest design. Populasi sampel adalah seluruh siswa yang terdiri dari 7 kelas. Pengambilan sampel dilakukan dengan cara cluster random sampling kelas X-2 terpilih sebagai kelas eksperimen dan kelas X-3 terpilih sebagai kelas kontrol. Instrumen yang digunakan berupa tes hasil belajar berupa esai dengan jumlah 9 soal dan lembar observasi aktivitas siswa. Hasil uji normalitas dan uji homogenitas diperoleh data berdistribusi normal dan homogen. Setelah diberi perlakuan hasil penelitian menunjukkan ada perbedaan signifikan akibat pengaruh dari penggunaan model pembelajaran berbasis masalah terhadap hasil belajar fisika dan aktiitas belajar siswa pada materi pokok listrik dinamis di kelas X semester II SMA Muhammadiyah 8 Kisaran T.A. $2014 / 2015$.
\end{abstract}

Kata kunci : pembelajaran berbasis masalah, konvensional, hasil belajar, aktivitas.

\section{ABSTRACT}

Education is a conscious and deliberate effort to create an learning environment and the learning process so that learners are actively developing their potential. The aim of the study is to know the differences due to the influence of problem-based learning with the result of student's learning and activities. This type of research is a quasi-experimental design with two group pretest-posttest design. The sample population was all of the students which consist of 7 classes. The Sample will be taken by cluster random sampling. class $X-2$ was chosen as the experimental class and the class $X-3$ was chosen as the control class. Instruments was used in the form of learning outcomes in the form of an essay test with the number 9 and the matter of student activity observation sheet. The results of normality test and homogeneity test was distributioned normally and homogeneous. Having treated the results showed no significant difference due to the 
influence of the use of problem-based learning model to the learning outcomes of physics and student's activity in dynamic electrict on the second half of the class X SMA Muhammadiyah 8 Kisaran at 2014/2015.

\section{Keywords: problem-based learning, conventional, learning outcomes, student activities.}

\section{PENDAHULUAN}

Sistem Pendidikan Nasional telah ditetapkan dalam UU RI No. 20 Pasal 1 Tahun 2003 yang menyatakan bahwa "Pendidikan adalah usaha sadar dan terencana untuk mewujudkan suasana belajar dan proses pembelajaran agar peserta didik secara aktif mengembangkan potensi dirinya untuk memiliki kekuatan spiritual keagamaan, pengendalian diri, kepribadian, kecerdasan, akhlak mulia, serta keterampilan yang diperlukan dirinya, masyarakat, bangsa dan negara". Pendidikan berkewajiban mempersiapkan generasi baru yang sanggup menghadapi tantangan zaman. Sehingga dunia pendidikan mempersiapkan sumber daya manusia yang kreatif, dalam memecahkan persoalan-persoalan yang aktual dan mampu menghasilkan teknologi baru. Masalah pokok pendidikan masih berkisar pada rendahnya minat belajar siswa, rendahnya kualitas peserta didik yang dihasilkan, dan hasil belajar yang dicapai siswa selama bertahun-tahun masih belum mencapai kelayakan yang diharapkan. Sehingga para peserta didik yang dihasilkan dari sekolah masih belum memenuhi tujuan yang dipaparkan dalam undang-undang.

Masalah utama dalam pembelajaran pada pendidikan formal adalah rendahnya hasil belajar peserta didik. Hal ini tampak dari rata-rata hasil belajar peserta didik yang masih sangat memperihatinkan. Rendahnya hasil belajar merupakan hasil kondisi pembelajaran yang masih bersifat konvensional dan tidak menyentuh ranah dimensi peserta.

Bidang studi sains fisika sebagai bagian dari Ilmu Pengetahuan Alam (IPA) merupakan objek mata pelajaran yang menarik dan lebih banyak memerlukan pemahaman dari pada penghafalan. Kenyataannya fisika sering dipandang sebagai suatu ilmu yang abstrak oleh siswa dengan teori dan soal-soal yang sulit. Berdasarkan pengalaman penulis saat melakukan Program Pengalaman Lapangan Terpadu (PPLT), dalam kegiatan belajar mengajar siswa hanya diberikan teori-teori dan cara menyelesaikan soal-soal fisika tanpa mengarahkan siswa untuk menemukan konsep fisika melalui eksperimen. Hal tersebut menyebabkan siswa menjadi tidak aktif dan kreatif sehingga pelajaran fisika menjadi membosankan dan menjadi salah satu pelajaran yang sulit dipelajari dan tidak disukai oleh siswa. Akibatnya siswa kurang mampu memahami dan menerapkan konsep fisika dalam kehidupan seharihari. Hal ini dapat dilihat dari nilai hasil ujian tengah semester yang dicapai siswa hanya berkisar 31,00 sampai 60,00 dengan rata-rata 35,8. Sedangkan Kriteria Ketuntasan Minimum (KKM) yang harus dicapai adalah 75. Hal ini membuktikan bahwa hasil belajar siswa di SMA Muhammadiyah 8 Kisaran masih sangat rendah dari nilai yang diharapkan. Rendahnya hasil belajar siswa disebabkan kurang pedulinya 
siswa terhadap mata pelajaran fisika, hal ini ditinjau dari angket yang disebarkan kepada 29 siswa. Berdasarkan angket diperoleh bahwa $62,06 \%$ siswa jarang mengulang pelajaran fisika dan $27,58 \%$ tidak pernah mengulang pelajaran fisika di rumah, $93,1 \%$ siswa tidak pernah mengikuti bimbingan di luar sekolah. Penyebab kurang pedulinya siswa terhadap mata pelajaran fisika adalah kurangnya kreativitas guru dalam mengajar di kelas, hal ini diperoleh dari $89,65 \%$ siswa yang menjawab bahwa dalam kegiatan belajarmengajar mereka hanya mencatat dan mengerjakan soal-soal, $55,17 \%$ menjawab bahwa guru membuka pelajaran hanya dengan menanyakan tugas saja. Kurangnya minat belajar siswa juga disebabkan oleh minimnya penggunaan sarana dan prasarana pendukung pada pelajaran fisika, hal ini dapat dibuktikan dari 37,93\% siswa yang menjawab jarang dan $41,37 \%$ siswa yang menjawab bahwa guru tidak pernah menggunakan media pendukung pembelajaran seperti alat peraga, poster, infokus, dan sebagainya. Selain itu, guru juga kurang memanfaatkan laboratorium fisika yang tersedia, terbukti $96,55 \%$ siswa menjawab bahwa mereka tidak pernah melakukan praktikum fisika di laboratorium. Semua permasalahan tersebut menyebabkan siswa kurang berminat terhadap mata pelajaran fisika. Terbukti bahwa $68,97 \%$ siswa mengatakan fisika sulit dan kurang menarik, dan $20,69 \%$ siswa mengatakan fisika biasa saja.

Rendahnya hasil belajar siswa berdasarkan hasil wawancara guru fisika tersebut disebabkan oleh: (1) Model pembelajaran fisika kurang bervariasi (model konvensinal), dimana proses belajar mengajar yang dilakukan terpusat pada guru (teacher centered), dengan urutan menjelaskan, memberi contoh, latihan dan penugasan. Variasi metode pembelajaran yang diberikan guru tidak disesuaikan berdasarkan karakteristik materi pelajaran yang diajarkan. (2) Guru jarang sekali memberikan kesempatan kepada siswa untuk berintraksi dengan teman sejawat atau dengan guru dalam upaya mengembangkan pengetahuan siswa yang menyebabkan mereka menjadi pasif dan sulit untuk memahami dan menguasai materi pelajaran, sehingga hasil belajar yang diperoleh siswa tidak maksimal.

Peneliti berusaha mengatasi masalah siswa dengan mengajukan model pembelajaran berbasis masalah karena pembelajaran berbasis masalah merupakan model pembelajaran yang berorientasi pada kerangka kerja teoritik konstruktivisme. Dalam model pembelajaran berdasarkan masalah, fokus pembelajaran ada pada masalah yangh dipilih sehingga pebelajar tidak saja mempelajari konsep-konsep yang berhubungan masalah tetapi juga metode ilmiah untuk memecahkan masalah tersebut. Oleh sebab itu, pebelajar tidak saja harus memahami konsep yang relevan dengan masalah yang menjadi pusat perhatian tetapi juga memperoleh pengalaman belajar yang berhubungan dengan keterampilan meneralpkan metode ilmiah dalam pemecahan masalah dan menumbuhkan pola berfikir kritis .

Strategi pembelajaran berbasis masalah mengusung gagasan utama bahwa tujuan pembelajaran dapat tercapai jika kegiatan pendidikan dipusatkan pada tugas-tugas atau permasalahan yang otentik, relevan dan dipresentasikan dalam satu konteks. 
Arends (2012) menyatakan bahwa model pembelajaran berbasis masalah merupakan suatu pendekatan pembelajaran dimana siswa mengerjakan permasalahan yang autentik dengan maksud untuk menyusun pengetahuan mereka sendiri dan keterampilan berpikir tingkat lebih tinggi.

Tujuan dari penelitian adalah 1) Untuk mengetahui hasil belajar siswa yang diajar menggunakan model pembelajaran berbasis masalah dan hasil belajar siswa yang diajar menggunakan pembelajaran konvensional. 2) Untuk mengetahui aktivitas belajar siswa yang diajar menggunakan model pembelajaran berbasis masalah dan aktivitas belajar siswa yang diajar menggunakan pembelajaran konvensional. 3) Untuk mengetahui akibat dari model pembelajaran berbasis masalah terhadap hasil belajar dan aktivitas siswa.

\section{METODE PENELITIAN}

Penelitian dilaksanakan di SMA Muhammadiyah 8 Kisaranyang beralamat di Jl. Madong Lubis Mutiara Kisaran yang dilaksanakan dari bulan Januari sampai Juni 2015.

Populasi dalam penelitian adalah siswa kelas X SMA Muhammadiyah 8 Kisaran yang terdiri dari 7 kelas yang berjumlah 246 siswa. Sampel dalam penelitian adalah siswa kelas X SMA Muhammadiyah 8 Kisaran tahun pelajaran 2014/2015. Pengambilan sampel dilakukan secara cluster random sampling sebanyak dua kelas yaitu kelas $X_{2}$ dan $X_{3}$. Kelas $X_{2}$ dijadikan sebagai kelas eksperimen yaitu kelas yang diajar menggunakan model pembelajaran berdasarkan masalah dan kelas $X_{3}$ dijadikan sebagai kelas kontrol yaitu kelas yang diajari dengan menggunakan

pembelajaran konvensional.

Variabel bebas dalam penelitian adalah pembelajaran dengan menggunakan model pembelajaran berdasarkan masalah dan model pembelajaran konvensional. Variabel terikat dalam penelitian adalah hasil belajar fisika siswa dan aktivitas belajar siswa pada materi pokok listrik dinamis.

Jenis penelitian adalah quasi eksperimen yaitu merupakan penelitian yang dimaksudkan untuk mengetahui ada tidaknya akibat dari sesuatu yang dikenakan pada subjek didik. Dengan kata lain penelitian quasi eksperimen mencoba meneliti ada tidaknya hubungan sebab akibat. Caranya dengan membandingkan satu atau lebih kelompok eksperimen yang diberikan perlakuan dengan membandingkan satu atau lebih kelompok pembanding yang tidak diberikan perlakuan.

Desain penelitian yang dipergunakan adalah two group pretest-posttest desaign. Pretest dan postest diberikan untuk mengetahui hasil belajar siswa. Pretest diberikan sebelum diberi perlakuan dan posttest diberikan setelah diberi perlakuan. Penelitian ini menerapkan dua perlakuan yang berbeda dan sampel kelompok eksperimen diterapkan pembelajaran model berdasarkan masalah kemudian pada kelompok kontrol tidak dilakukan perlakuan. Rancangan penelitian dapat dilihat pada Tabel 1.

Tabel 1. Rancangan Penelitian Two Group Pretest - Posttest Control Group Design

\begin{tabular}{lccc}
\hline Sampel & Pretest & $\begin{array}{c}\text { Perlakua } \\
\mathbf{n}\end{array}$ & $\begin{array}{c}\text { Postes } \\
\mathbf{t}\end{array}$ \\
\hline Kelas & $\mathrm{T}_{1}$ & $\mathrm{X}_{1}$ & $\mathrm{~T}_{2}$ \\
Eksperimen & & & \\
\hline
\end{tabular}




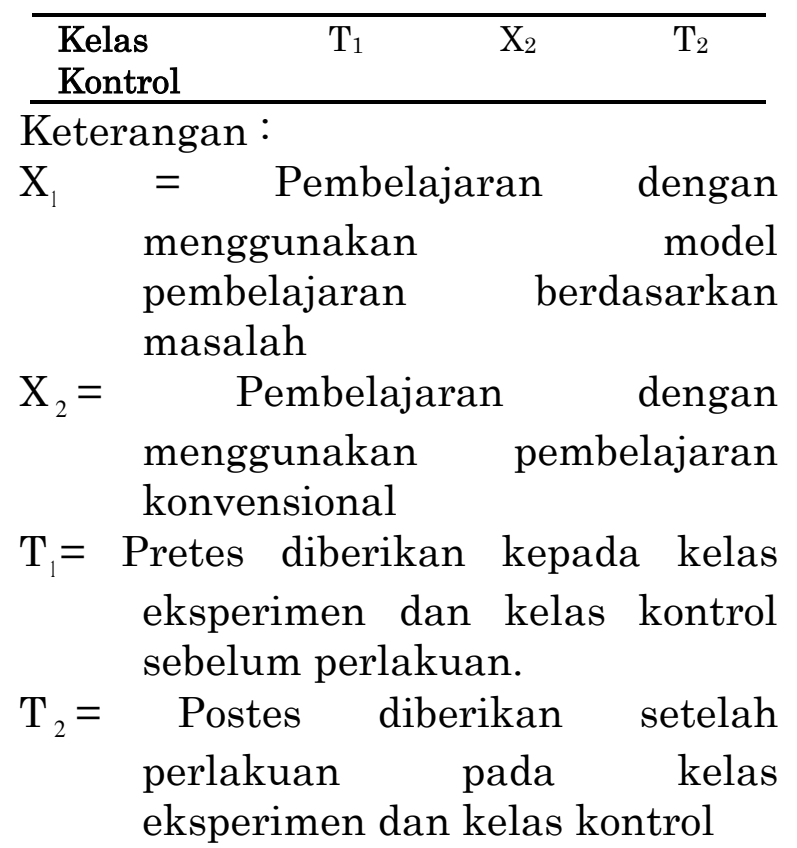

Tes hasil belajar digunakan untuk mengukur penguasaan kognitif siswa pada materi pokok listrik dinamis. Tes disusun berdasarkan taksonomi Bloom dalam ranah kognitif, yaitu ingatan $\left(\mathrm{C}_{1}\right)$, pemahaman $\left(\mathrm{C}_{2}\right)$, aplikasi $\left(\mathrm{C}_{3}\right)$, analisis $\left(\mathrm{C}_{4}\right)$, evaluasi $\left(\mathrm{C}_{5}\right)$, dan mencipta $\left(\mathrm{C}_{6}\right)$, (Arikunto 2009 : 245). Peneliti hanya menggunakan ranah kognitif $\left(\mathrm{C}_{4}\right),\left(\mathrm{C}_{5}\right)$, dan $\left(\mathrm{C}_{6}\right)$. Spesifikasi tes hasil belajar dapat dilihat pada Tabel 2.

Tabel 2. Spesifikasi Tes Hasil Belajar Siswa

\begin{tabular}{|c|c|c|c|c|}
\hline \multirow[t]{2}{*}{ No } & \multirow[t]{2}{*}{$\begin{array}{c}\text { Materi Pokok/Sub } \\
\text { Materi Pokok }\end{array}$} & \multicolumn{3}{|c|}{$\begin{array}{c}\text { Tingkat } \\
\text { Kemampuan } \\
\text { Kognitif }\end{array}$} \\
\hline & & $\mathrm{C}_{4}$ & $\mathrm{C}_{5}$ & $\mathrm{C}_{6}$ \\
\hline 1 & $\begin{array}{l}\text { Beda Potensial dan } \\
\text { Arus Listrik }\end{array}$ & 1,3 & 4,8 & \\
\hline 2 & Hukum Ohm & 6,7 & & \\
\hline 3 & $\begin{array}{l}\text { Jenis Susunan } \\
\text { Rangkaian }\end{array}$ & 9 & & 2,5 \\
\hline & Jumlah & 5 & 2 & 2 \\
\hline
\end{tabular}

Keterangan :

$\mathrm{C}_{4}=$ Menganalisis

$\mathrm{C}_{5}=$ Mengevaluasi

$\mathrm{C}_{6}=$ Mencipta

Observasi aktivitas siswa dalam proses pembelajaran dilakukan agar mengetahui apakah model pembelajaran yang diterapkan mengakibatkan timbulnya berbagai aktivitas siswa yang mendukung siswa.

Uji validitas yang digunakan pada penelitian ini adalah validitas isi. Sebuah tes dikatakan memiliki validitas isi apabila mengukur tujuan khusus tertentu yang sejajar dengan materi atau isi pelajaran yang diberikan (Arikunto, 2009:67).Dalam validitas isi, item-item soal akan divalidkan oleh tim ahli sebagai validator, dalam hal ini adalah dua orang dosen fisika, dan satu orang guru fisika yang sudah bersertifikasi. Validitas dilihat dari sisi materi soal, konstruksi dan bahasa.

\section{HASIL PENELITIAN}

Data dari hasil penelitian diperoleh nilai rata-rata pretes siswa pada kelas eksperimen sebelum diberi perlakuan dengan menggunakan model pembelajaran berdasarkan masalah adalah sebesar 34,07 dengan standar deviasi 9,36. Berbeda dengan kelas kontrol, nilai rata-rata pretes pada kelas kontrol lebih rendah dari nilai rata-rata kelas eksperimen yaitu sebesar 33,79 dengan standar deviasi 10,27.Ringkasan hasil pretes untuk kedua sampel diringkas pada Tabel 4. 
Tabel 4. Data Pretes Kelas Eksperimen dan Kelas Kontrol

\begin{tabular}{lcclcc}
\hline \multicolumn{4}{l}{ Kelas Eksperimen } & \multicolumn{4}{l}{ Kelas Kontrol } \\
\hline Nilai & $\begin{array}{c}\text { Frekuens } \\
\text { i }\end{array}$ & $\begin{array}{c}\text { Rata- } \\
\text { rata }\end{array}$ & Nilai & $\begin{array}{c}\text { Frekuens } \\
\text { i }\end{array}$ & Rata-rata \\
$15-21$ & 3 & 34,07 & $15-21$ & 2 & 33,79 \\
$22-28$ & 5 & & $22-28$ & 9 & \\
$29-35$ & 9 & & $29-35$ & 6 & \\
$36-42$ & 8 & & $36-42$ & 7 & \\
$43-48$ & 3 & $43-48$ & 4 & \\
$49-55$ & 2 & & $49-55$ & 2 & \\
$\sum=30$ & & & $\sum=30$ & & \\
\hline
\end{tabular}

Uji normalitas dilakukan kemampuan awal siswa pada kelas sebelum uji hipotesis dengan menggunakan uji liliefors. Hasil uji normalitas yang diperoleh adalah $\mathrm{L}_{\text {hitung }}<\mathrm{L}_{\text {tabel }}$ sehingga dapat diartikan data hasil pretes kedua kelas berdistribusi normal.

Uji homogenitas dilakukan untuk mengetahui apakah kelas sampel berasal dari populasi yang homogen atau tidak, artinya apakah sampel yang dipakai dalam penelitian ini dapat mewakili seluruh populasi yang ada. Pengujian homogenitas data dilakukan dengan uji F. Hasil uji homogenitas data yang diperoleh adalah $\mathrm{F}_{\text {hitung }}<\mathrm{F}_{\text {tabel }}$ yang berarti bahwa sampel yang digunakan dalam penelitian dinyatakan homogen atau dapat mewakili seluruh populasi yang ada. Hasil uji beda kemampuan awal siswa yaitu $t_{\text {hitung }}<t_{\text {tabel }}$ dengan nilai $0,11<1,988$ maka $\mathrm{H}_{0}$ diterima, sehingga dapat disimpulkan bahwa eksperimen dengan kemampuan awal siswa pada kelas kontrol. Hasil pretes kedua kelas normal, homogen dan tidak ada perbedaan secara signifikan. Kedua kelas sampel diberikan perlakuan yang berbeda, kelas eksperimen diberikan perlakuan dengan menerapkan model pembelajaran berdasarkan masalah, kelas kontrol diberikan perlakuan dengan menerapkan model pembelajaran konvensional. Kedua kelas diberikan postes. Hasil yang diperoleh adalah, nilai ratarata postes kelas eksperimen setelah diterapkan model pembelajaran berdasarkan masalah sebesar 62,87 dengan standar deviasi 10,013. Kelas kontrol diperoleh nilai rata-rata postes siswasebesar 53,89 dengan standar deviasi 7,53. Ringkasan postes kelas eksperimen dan kelas kontrol tedapat pada Tabel 5 .

Tabel 5. postest kelas eksperimen dan kelas kontrol

\begin{tabular}{|c|c|c|c|c|c|}
\hline \multicolumn{3}{|c|}{ Kelas Eksperimen } & \multicolumn{3}{|c|}{ KelasKontrol } \\
\hline Nilai & Frekuensi & Rata-rata & Nilai & Frekuensi & Rata-rata \\
\hline $50-56$ & 9 & & $44-48$ & 10 & \\
\hline $57-63$ & 6 & & $49-53$ & 7 & \\
\hline $64-70$ & 10 & 62,87 & $54-58$ & 5 & 53,89 \\
\hline $71-77$ & 2 & & $59-63$ & 3 & \\
\hline $78-84$ & 2 & & $64-68$ & 4 & \\
\hline $85-91$ & 1 & & $69-73$ & 1 & \\
\hline \multicolumn{2}{|r|}{ 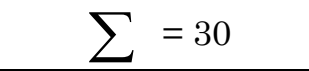 } & \multicolumn{3}{|c|}{$\sum=30$} & \\
\hline \multicolumn{2}{|c|}{ Standar deviasi } & 10,01 & \multicolumn{2}{|c|}{ Standar deiasi } & 7,53 \\
\hline
\end{tabular}


Uji hipotesis dilakukan sebelum uji prasyarat data yaitu uji normalitas menggunakan uji liliefors. Hasil uji normalitas yang diperoleh adalah Lhitung $<$ Ltabel sehingga disimpulkan bahwa data postes dari kedua kelas berdistribusi normal.

Pengujian homogenitas data dilakukan dengan uji F. Hasil uji homogenitas data yang diperoleh adalah $\mathrm{F}_{\text {hitung }}<\mathrm{F}_{\text {tabel }}$ yang berarti bahwa sampel yang digunakan dalam penelitian dinyatakan homogen atau dapat mewakili seluruh populasi yang ada. Hasil pengujian hipotesis nilai postes adalah thitung $>t_{\text {tabel }}$ yaitu 4,045>1,998 maka $\mathrm{H}_{0}$ ditolak dan $\mathrm{H}_{\mathrm{a}}$ diterima dan disimpulkan bahwa hasil belajar siswa pada kelas eksperimen lebih besar dari hasil belajar kelas kontrol, berarti ada perbedaaan hasil belajar dengan menggunakan model pembelajaran berbasis masalah terhadap hasil belajar fisika siswa pada materi pokok listrik dinamis di kelas X semester II SMA Muhammadiyah 8 Kisaran T.A 2014/2015.

Observasi dilakukan selama kegiatan belajar mengajar yang dilakukan selama tiga kali pertemuan. Hasilobservasi aktivitas para observer untuk kelas eksperimen dan kelas kontrol.

Hasil Pengamatan aktivitas siswa kelas eksperimen yang ditunjukkan pada Tabel 6 .

Tabel 6. Rata-Rata Aktivitas Siswa Kelas Eksperimen

\begin{tabular}{|c|c|c|}
\hline \multicolumn{2}{|c|}{ No. $\mathrm{n}$} & Aktivitas Siswa \\
\hline 1. & $\bar{I}$ & 69,79 \\
\hline 2. & II & 74,90 \\
\hline 3. & III & 82,46 \\
\hline & & 75,72 \\
\hline
\end{tabular}

Terjadi peningkatan aktivitas siswa dalam proses pembelajaran dari pertemuan pertama sampai ketiga. Rata-rata nilai keseluruhan sebesar 75,72 (kategori aktif). Persentasi aktivitas untuk tiap kategori yaitu: $13,3 \%$ mendapat kategori sangat aktif dan 86,7\% mendapat kategori aktif, baik dalam memperoleh informasi dan proses penemuan serta pemecahan masalah. Pengamatan aktivitas siswa kelas kontroldapat dilihat pada Tabel 7.

Tabel 7. Rata-rata aktivitas siswa kelas kontrol

\begin{tabular}{|c|c|c|c|}
\hline No. & Pertemuan & $\begin{array}{l}\text { Rata-rata } \\
\text { Aktivitas Siswa } \\
\end{array}$ & Kriteria \\
\hline 1. & I & 46,88 & $\begin{array}{l}\text { Cukup } \\
\text { Aktif }\end{array}$ \\
\hline 2. & II & 51,38 & $\begin{array}{l}\text { Cukup } \\
\text { Aktif }\end{array}$ \\
\hline 3. & III & 63,13 & $\begin{array}{l}\text { Cukup } \\
\text { Aktif }\end{array}$ \\
\hline & $\bar{x}$ & 53,79 & $\begin{array}{l}\text { Cukup } \\
\text { Aktif }\end{array}$ \\
\hline
\end{tabular}

Berdasarkan Tabel 7, memiliki rata-rata nilai keseluruhan 53,79 (kategori cukup aktif). Perbandingan nilai observasi aktivitas kedua kelas menunjukkan bahwa pada kelas eksperimen aktivitas siswa lebih tinggi dibandingkan kelas kontol. Hal ini menunjukkan bahwa model pembelajaran berdasarkan masalah meningkatkan aktivitas belajar siswa.Hasil penelitian menunjukkan bahwa ada pengaruh menggunakan model pembelajaran berdasarkan masalah terhadap hasil belajar fisika siswa pada materi pokok Listrik Dinamis Di kelas X semester II SMA Muhammadiyah 8 Kisaran T.A 2014/2015. Hal ini diperkuat dengan adanya perbedaan peningkatan aktivitas siswa dan hasil belajar kelas eksperimen.

$$
\text { Hasil pengamatan yang }
$$
dilakukan oleh observer di kelas 
eksperimen

aktivitas

diperoleh

bahwa

siswa

mengalami

peningkatan yang positif. Pada

pertemuan I rata-rata aktivitas siswa

diperoleh sebesar 69,79. Hal ini

terjadi karena siswa belum terbiasa dengan model pembelajaran

berdasarkan masalah hingga

instruksi dan motivasi yang diberikan peneliti kurang dimengerti oleh beberapa orang siswa. Peneliti terus memberikan instruksi dan arahan kepada siswa hingga siswa paham dan termotivasi dalam mengikuti proses pembelajaran seperti mengerjakan LKS. Pertemuan II diperoleh peningkatan terhadap aktivitas siswa dengan nilai rata-rata 74,90 . Karena siswa sudah mulai memahami proses pembelajaran berdasarkan masalah dan tugas mereka serta tanggung jawab mereka dalampembelajaran.PertemuanIIIdip erolehpeningkatan yang positif terhadap aktivitas siswa dengan nilai rata-rata 82,46 . Hal ini karena siswa sudah memahami proses pembelajaran berdasarkan masalah atau pemecahan masalah dan tugas mereka serta tanggung jawab mereka dalam pembelajaran. Rata-rata nilai keseluruhan aktivitas belajar siswa adalah 75,72 dan termasuk dalam kategori aktif. Ternyata, aktivitas siswa yang dikategorikan aktif sejalan dengan peningkatan hasil belajar siswa yang meningkat dari nilai 34,07 menjadi 62,87. Aktivitas siswa memiliki pengaruh positif terhadap hasil belajar yaitu semakin aktif siswa maka hasil belajarnya juga meningkat karena siswa terbiasa dituntut untuk berfikir kritis.

Hasil observasi aktivitas untuk kelas kontrol pada pertemuan I rataratanya adalah 46,88 dan pada pertemuan II rata-ratanya adalah
51,38 dan pada pertemuan III rataratanya adalah 63,13 serta nilai ratarata akhir adalah 53,80 katagori cukup aktif. aktivitas kelas kontrol lebih rendah dari kelas eksperimen. Siswa kelas kontrol yang aktif dalam belajar sangatlah sedikit masih banyak siswa yang pasif. Hal ini dikarenakan kegiatan pembelajaran kelas eksperimen lebih bervariasi daripada kelas kontrol. Pembelajaran berbasis masalah lebih menekankan proses pembelajaran berpusat pada siswa, sehingga siswa lebih terbiasa berfikir kritis dalam memecahkan masalah dan lebih tertarik uuntk belajar. Berdasarkan penjelasan diatas menunjukkan bahwa model pembelajaran berbasis masalah meningkatkan aktivitas belajar siswa di kelas eksperimen.

Kelas eksperimen yang diberikan perlakuan dengan menerapkan model pembelajaran berbasis masalah hasil belajar siswa berbeda dengan kelas kontrol yang diajarkan dengan model pembelajaran konvensional yang sebelumnya telah diketahui memiliki kesamaan kemampuan awalnya yaitu 34,07 untuk kelas eksperimen dan 33,79 untuk kelas kontrol dengan $t_{\text {hitung }}<\quad t_{\text {tabel }} \quad(-1,988<0,11<1,988)$. Mengetahui peningkatan hasil belajar siswa atau kemampuan akhir siswa dapat dilakukan dengan memberikan postes kepada kedua kelas. Hasil belajar yang diperoleh adalah nilai rata-rata hasil belajar untuk kelas eksperimen adalah 62,87 sedangkan untuk kelas kontrol adalah 53,89. Berdasarkan data di atas, dapat dilihat bahwa nilai ratarata postes di kelas eksperimen lebih tinggi daripada nilai rata-rata di kelas kontrol.

Adanya perbedaan peningkatan hasil belajar siswa 
kedua kelas sebesar 8,98, dan thitung $>$ tabel $\quad(4,045>1,988), \quad$ dapat disimpulkan bahwa ada pengaruh model pembelajaran berbasis masalah pada materi pokok listrik dinamis pada kelas X SMA Muhammadiyah 8 Kisaran. Hasil penelitian sesuai dengan hasil penelitian yang dilakukan oleh (Kharida,2009) penerapan model pembelajaran berbasis masalah dapat meningkatkan hasil belajar siswa dan meningkatkan aktivitas belajar siswa. tapi nilai postes kelaskontrol dan kelas eksperimen masih belum mencapai KKM (Kriteria Ketuntasan Minimum). Hal ini disebabkan oleh beberapa faktor diantaranya: 1) peneliti yang masih kurang piaway dalam melaksanakan pembelajaran, 2) soal kurang relevan dengan materi pada LKS, 3) siswa yang kurang memperdulikan jawaban soal.

Peningkatan hasil belajar tidak sejalan dengan penigkatan nilai LKS yang tidak stabil, yaitu terjadi peningkatan pada petemuan I ke pertemuan II dan terjadi penurunan pada pertemuan II ke pertemuan III. Kalkulasi 31 menjadi 67 dan menurun menjadi 50. Ketidak stabilan ini karena siswa kurang mampu menjawab hipotesa dari permasalahan yang diajukan. Peningkatan nilai LKS pada pertemuan I dan pertemuan II sesuai dengan hasil penelitian yang diperoleh peneliti sebelumnya, (Tika, 2008) menyatakan bahwa penerapan problem based learning meningkatkan keempat kerja aspek ilmiah yaitu aspek kegiatan laboratorium, pembuatan paper, penyusunan laporan praktikum dan penyajian tugas proyek.

Peningkatan hasil belajar menggunakan model pembelajaran berbasis masalah lebih tinggi dikarenakan model pembelajaran ini memiliki beberapa kelebihan yaitu : 1) siswa belajar untuk memperoleh pengetahuan dan melatih kemampuan intelektual mereka; 2) merangsang keingintahuan dan memotivasi kemampuan siswa; 3) siswa didorong untuk belajar sendiri, belajar aktif melalui konsep-konsep, prinsip-prinsip; 4) mengajarkan siswa untuk memahami isi dan proses dalam waktu yang bersamaan; 5) siswa belajar menyelesaikan masalah, mengevaluasi solusi, dan berfikir logis, hal ini dapat dilihat pada saat siswa bekerja bersama kelompok mengemukakan hipotesis mereka.

\section{KESIMPULAN}

Kesimpulan yang diperoleh antara lain : 1) Hasil belajar fisika siswa yang diberi pembelajaran dengan model pembelajaran berdasarkan masalah diperoleh ratarata postes sebesar 62,87. Hasil belajar fisika siswa yang diberi pembelajaran dengan model konvensional diperoleh rata-rata postes sebesar 53,89. 2) Aktivitas belajar siswa di kelas eksperimen dengan model pembelajaran berdasarkan masalah di kelas eksperimen mengalami peningkatan yaitu siswa lebih aktif dalam kegiatan pembelajaran, saling bekerja sama dalam kelompok dan memecahkan masalah serta lebih berfikir kritis. Pada pertemuan I rata-rata aktivitas siswa 69,79, pertemuan II rata-rata 74,90, pertemuanke III rata-rata 84,46. Aktivitas belajar siswa di kelas kontrol dengan model pembelajaran konvensional mengalami peningkatan yang positif tetapi tidak lebih baik dari kelas eksperimen. Pada pertemuan I rata-rata aktivitas siswa 
46,88, pertemuan II rata-rata 51,38, pertemuan III rata-rata 63,13 . 3)Ada perbedaan akibat pengaruh yang signifikan antara hasil belajar siswa dengan model pembelajaran berdasarkan masalah dan model pembelajaran konvensional.

\section{DAFTAR PUSTAKA}

Arends, R., (2012), Learning to Teach Ninth Edition, Yogyakarta: Pustaka Pelajar

Arikunto, S., (2012), Dasar-Dasar Evaluasi Pendidikan, Jakarta: Bumi Aksara

Arikunto, S., (2009), Dasar-dasar Evaluasi Pendidikan, Bumi Aksara, Jakarta.

Kharida, (2009), Penerapan Model Pembelajaran Berbasis Masalah Untuk Peningkatan Hasil Belajar Siswa Pada

Purwanto, (2011), Evaluasi Hasil Belajar, Pustaka Belajar, Yogyakarta.

Tika, K. I, (2008), Penerapan Problem Based Learning Berorientasi Penilaian Kinerja dalam Pembelajaran Fisika Untuk Meningkatkan Kompetensi Kerja Ilmiah Siswa,Jurnal Pendidikan dan Pengajaran UNDIKSHA 3 TH.XXXXI. 